\title{
Sınıf Öğretmenlerinin Yazılı Anlatımı Değerlendirme Ölçütleri
}

DOI: 10.26466/opus.890147

$*$

İhan Polat * - Hakan Dedeoğlu *

* Dr. Öğr., Hacettepe Üniversitesi, Eğitim Bilimleri Enstitüsü, Ankara/Türkiye E-Posta: ilhan polatt@hotmail.com

ORCID: $\quad$ 0000-0002-7802-6337

** Doç. Dr., Hacettepe Üniversitesi Eğitim Fakültesi, Temel Eğitim Bölümü, Ankara/Türkiye

E-Posta: dede@hacettepe.edu.tr

ORCID: $\quad \underline{0000-0003-2436-7010}$

Öz

Bu çalışmanın amacl; sınıf öğretmenlerinin, öğrenci metinlerini hangi ölçütlere göre değerlendirdiğini araştırmaktır. Bu amaç doğrultusunda çalışma, nitel araştırma yönteminde durum çalı̧̧ması deseni olarak tasarlanmıştır. Araştırmanın katılımcılarını 11'i kadın 25'i erkek olmak üzere toplam 36 sınıf öğretmeni oluşturmaktadır. Veriler, araştırmacılar tarafından hazırlanan yarı yapılandırılmış görüşme formu aracılığıyla toplanmıştır. Verilerin analizinde betimsel analiz tekniği kullanılmıştır. Analizler sonucunda elde edilen bulgulara göre; öğretmenlerin yazılı anlatım çalışmalarında çoğunlukla hikâye edici metinlere yer verdiği, yazmaya çoğunlukla haftada 3-4 saat zaman ayırdığı, sinıfta genellikle hikâye tamamlama çalışması yaptıkları, değerlendirme yaparken çoğunlukla standart bir ölçme aracı kullanmadıkları sonucuna ulaşılmıştır. Metin türlerine göre değerlendirme ölçütlerine bakıldığında, hikâye edici metinleri değerlendirirken en fazla kâğıt düzeni, yazım kurallar ve noktalama işaretleri, kendini ifade etme becerisi, cümle yapısl, metin bütünlü̆ğü, vb. dikkat edildiği görülmektedir. Bilgilendirici metinleri değerlendirirken de en fazla kâğıt düzeni ve okunaklılık, yazım kuralları ve noktalama işaretleri, kendini ifade etme, kelimelerin doğru kullanımı, bilgilerin doğruluğu, düşünceyi geliştirme yolları, konuyu araştırma ve metin bütünlüğüne dikkat ettiği görülmektedir. Ancak genel olarak öğretmenlerin, hikâye edici ve bilgilendirici metinleri değerlendirme ölçütlerinin yeterli düzeyde olmadığı sonucuna ulaşılmıştır.

Anahtar Kelimeler: Sinıf Öğretmenleri, Yazılı Anlatım, Değerlendirme. 
ISSN:2528-9527

E-ISSN: 2528-9535

Yıl Year: 11

Cilt Volume: 18

Sayı Issue :Eğitim Bilimleri Özel Sayısı

Eylül September 2021

Uluslararası Toplum Araştırmaları Dergisi

International Journal of Society Researches

Makalenin Gelis Tarihi Received Date: 03/03/2021

Makalenin Kabul Tarihi Accepted Date: 26/04/2021

\title{
Primary School Teachers' Evaluation Criteria for Written Expression
}

*

\begin{abstract}
The aim of this study is; to investigate the criteria by which primary school teachers evaluate student texts. For this purpose, the study was designed as a case study pattern in qualitative research method. Participants of the study consist of a total of 36 primary school teachers, 11 women and 25 men. The data were collected through a semi-structured interview form prepared by the researchers. Descriptive analysis technique was used in the analysis of the data. According to the findings obtained as a result of the analysis; it has been concluded that teachers mostly include narrative texts in their written expression studies, spend 3-4 hours a week on written expression studies, generally do story completion work in the classroom, and mostly do not use a standard measuring tool when making evaluations. Looking at the evaluation criteria according to text types, it is seen that when evaluating the narrative texts, the most attention is paid to features such as paper layout, spelling rules and punctuation marks, self-expression skills, sentence structure, text integrity. When evaluating informative texts, it is seen that he pays attention to the layout and legibility, spelling rules and punctuation marks, self-expression, correct use of words, accuracy of information, ways of developing thinking, researching the subject and text integrity. However, it was concluded that generally, teachers' evaluation criteria for narrative and informative texts were not sufficient.
\end{abstract}

Keywords: Primary school teachers, Written expression, Evaluation. 


\section{Giriş}

Dil eğitiminde temel dil becerileri; dinleme, konuşma, okuma ve yazma olarak ifade edilmektedir. Milli Eğitim Bakanlığı (MEB) Türkçe dersi öğretim programında bu beceriler şöyle ifade edilmiştir; "Öğrencilerin bireysel ve sosyal yönden gelişmeleri, etkili iletişim kurmaları, Türkçe sevgisiyle, istek duyarak okuma ve yazma alışkanlığı edinmelerini sağlayacak şekilde; bilgi, beceri ve değerleri içeren bir bütünlük içinde yapılandırılmıştır" (MEB, 2019, s.8). Temel dil becerilerinden biri olan yazma, zihinde yapılandırılmış bilgi, duygu, düşünce, istek ve olayların belli kurallara göre yazıya aktarılma işlemi olarak tanımlamaktadır (Coşkun, 2014; Güneş, 2019). Vygotsky'e (1998) göre yazı yazma, bilinçli bir çabadır ve çocuğun çözümleyici bir eyleme girişmesini gerektirdiği için yazmada zihinsel işlemler kullanılır (Aktaran Karakoç-Öztürk 2014). Yazma ile ilgili tanımlara bakıldığında yazma becerisi, duygu, düşünce, istek ve olayları dilin kuralları içinde semboller kullanılarak bilinçli ve planlı bir şekilde yazıya dökme süreci olarak ifade edilmektedir. Yazma eylemi, iletişim kurmak için en etkili yollardan biridir ve sosyalleşme aracıdır. Yazma eylemi sadece akla gelenlerin semboller yoluyla aktarılması şeklinde basit bir eylemden ziyade duygu, düşünce ve isteklerin önceden organize edilmesi, kullanılan dilin özelliklerine göre düzenlenmesi, doğru anlatım yöntemlerinin seçilmesi ve nihayetinde karşıdakiyle iletişim kuracak ve doğru aktarım yapacak nitelikte bir yapıya dönüşmesidir. Yazma, birçok beceriyi birlikte kullanmayı gerektirdiğinden bu becerinin gelişimi için yazma öğretiminin iyi planlanması gerekmektedir.

Yazma öğretiminde amaç; iletişim ve dil becerilerinin arttırılması (Güneş, 2016), “öğrencilere duygu ve düşüncelerini etkili ve işlevsel biçimde ifade edebildikleri metinler oluşturma becerisi kazandırma" (Coşkun, 2005, s.5) şeklinde ifade edilmektedir. Yazma becerisi; okuma, dinleme ve konuşma becerilerini de gerektiren bir eylem olduğundan, diğer becerilerden daha geç ve zor gelişen bir beceridir. Yazma, eğitim gerektirmesinin yanı sıra, uzun bir süreç sonucunda elde edilebilecek bir dil becerisidir. Bu nedenle öğretimi programlı bir şekilde yürütülmelidir (Tabak ve Göçer, 2013). 
Yazma öğretiminde ve uygulamalarında iki yaklaşımdan söz edilmektedir: "Ürün Odaklı Yazma Yaklaşımı" ve "Süreç Odaklı Yazma Yaklaşımı" (Tabak ve Göçer, 2013). Ürün odaklı yazma yaklaşımında yazma işi bireyin kalemi eline alıp yazdığ 1 ve tek hamlede ürünün ortaya çıktığ 1 bir eylem olarak düşünülür. Öğretmen, öğrencinin bir metin oluşturmasını ister, hazırlık dâhil herhangi bir aşamada destek olmaz. Öğretmenin rolü konuyu vermek ve yazılanları değerlendirmektir. "Öğretmen, öğrencinin yazısını dilbilgisi, sözcük kullanımı, biçim gibi teknik ölçütlere göre değerlendiren kişi konumundadır" (Maltepe, 2006, s.31). Süreç odaklı yazma yaklaşımı ise öğrencilerin yazma sürecinde düşünme, karar verme, duygu ve düşüncelerini açı ve mantıklı bir biçimde sunabilme, düzenleme yapma gibi bir takım bilişsel becerilere sahip olmalarını gerektirmektedir (Karadağ-Yılmaz ve Erdoğan, 2019). "Süreç yaklaşımında yazma; öğrenme ve gelişmenin bir yolu, analiz edebilen ve tanımlanabilen belirli kurallara bağlı kalınarak düzenlenmiş yaratıcı bir etkinlik olarak görülmektedir"' (Maltepe, 2006, s.31). Yazma yaklaşımları, öğretmenin yazılı anlatım çalışmalarında çalışmaya tam olarak ne kadar dâhil olduğunu ve buna bağlı olarak öğrenci metinlerini nasıl değerlendirdiğini de şekillendirmektedir. Yazma yaklaşımlarının öğrenci ürününü ele alma biçimi oldukça farklılık göstermektedir.

Eğitim öğretim sürecinin en önemli unsurlarından biri değerlendirmedir. Değerlendirme, yapılan işin amacına ulaşıp ulaşmadığını ortaya koyma adına eğitim ve öğretim sürecindeki en önemli faaliyetlerden biridir. Bu süreçte gelişmenin takibi için, yazılı anlatım çalışmalarının öğretmen ve öğrenciler tarafından sürekli olarak değerlendirilmesi gerekir (Temizkan, 2008). Bu değerlendirmede amaç, öğrencileri bulundukları durum ve seviyeden daha üst seviyeye taşımak olmalıdır (Göçer, 2010). Yazılı anlatım çalışmalarında öğretmenin değerlendirmesi ve geribildirim vermesi çok önemlidir. Öğrenciler, kendilerinden bekleneni ürettiğinde takdir edilmek isterler (Temizkan, 2008). Bu açıdan bakıldığında öğrenci yazıları öğretmen tarafından değerlendirildiğinde öğrenci için bir anlam kazanır ve bir değer ifade eder (Zorbaz, 2013). Bu nedenle öğrencilerin yazılı anlatım çalışmaları mutlaka değerlendirilip, öğrenciye geribildirim verilmelidir. Değerlendirme ve geri bildirim, hem öğrenci motivasyonuna hem de yazma becerisinin gelişimine önemli katkı sağlayacaktır. Değerlendirme çalışmaları, öğrencinin geldiği se- 
viyeyi, eksikliklerini, bir sonraki çalışmada yapacaklarını belirlemek amacıyla yapılmakla birlikte, öğrencilerin ders notlarının belirlenmesinde de kullanılmaktadır.

İlkokulda yazılı anlatım çalışmaları genellikle öğretmenler tarafından değerlendirilmektedir. Alanyazına bakıldığında öğretmenlerin çoğunluğunun öğrencilerin metinlerini değerlendirirken yazının biçimsel özelliklerine ve içeriğin düzenlenmesine dikkat ettiği görülmektedir (Göçer, 2011; Lucero, Fernández ve Montanero, 2018; Karakoç-Öztürk 2014; Özbay, 2003; Temizkan, 2003; Ülper, 2012; Sarikaya ve Yılar, 2018). Bu çalışmalarda, öğretmenlerin yazılı anlatımı değerlendirme aşamasında, metin bütünlüğü, kâğıt düzeni, harflerin yazımı, dilbilgisi ve yazım kuralları, yazı okunaklığı, boşluklar vb. konulara dikkat ettiği ancak içerik, dil ve anlatım konularına yeterince önem vermedikleri tespit edilmiştir. Yazma becerisi zor gelişen, zaman alan ve süreklilik gerektiren bir beceri olduğundan yazılı anlatım çalışmalarına ayrılan zaman, becerinin gelişimi için oldukça önemlidir.

Alanyazına bakıldığında yazılı anlatım çalışmalarına yeteri kadar zaman ayrılmadığı görülmektedir (Brindle, Graham, Harris ve Hebert, 2015; Gilbert ve Graham, 2010; Ateş, 2017; Şimşek, 2015; Yamaç ve Öztürk, 2018). Yazılı anlatım çalışmalarında bir diğer önemli konu, çalışmaların değerlendirilmesinin nasıl yapıldığıyla ilgilidir. Bu konuda öğretmenlerin, yazılı anlatım becerisini değerlendirmek için standart ölçeklerden ziyade kendi ölçütlerini dikkate alarak değerlendirme yaptığ1 görülmektedir (Temizkan, 2003; Gelbal ve Kelecioğlu, 2007; Göçer, 2011; Çetin, 2002'den Akt. Zorbaz, 2013; Karakoç-Öztürk, 2014; Elma ve Bütün, 2015; Karakoç-Öztürk, 2016; Sarikaya ve Yılar, 2018; Karatay ve Dilekçi, 2019; Doğan-Kahtalı ve Çelik, 2020). Bununla birlikte öğretmenler, öğrencilerin yazılı anlatım becerisini değerlendirirken, bütünleşik ve sürece yayılmış değerlendirme yerine toplu değerlendirme yapmaktadırlar (Göçer, 2011). Bu durum, öğretmenlerin yaptığ1 değerlendirmelerin gerçek durumu yansıtmamasına ve bunun sonucunda da yazılı anlatım çalışmalarının amacından sapmasına yol açmaktadır. Çünkü öğretmenler ölçek kullanmadığında izlenimlerine ve kanaatlerine göre değerlendirme yapmaktadırlar. Öğretmenlerin izlenimle yaptığı değerlendirme, öğrencilerin yazma çalışmalarındaki belli unsurların öne çıkmasına ve objektif olmayan bir değerlendirmeye sebep olmaktadır 
(Zorbaz, 2013). Öğretmenlerin ölçek kullanmamasının altında birçok faktörden bahsedilebilir. Bu faktörlerden birinin de öğretmenlerin ölçek kullanımındaki yetersizliği olduğu düşünülmektedir. Nitekim alanyazında, öğretmenlerin ölçekleri kullanma konusunda sorunlar yaşadığı, ölçekler hakkında yeterli bilgiye sahip olmadığı, alternatif ölçme değerlendirme yöntemlerini kullanma konusunda eksik olduğu, ölçek kullanımı konusunda tam olarak ne yapacağını bilmediği ve kafa karışıklığı yaşadığı vurgulanmaktadır (Adıyaman, 2005; Gelbal ve Kelecioğlu, 2007; TED, 2009; Benzer ve Eldem, 2012; Uygun ve Katranc1, 2013; Crusan, Plakans ve Gebril, 2016; Doğan-Kahtalı ve Çelik, 2020).

Yazılı anlatım çalışmalarında değerlendirmeyi etkileyen en önemli faktörlerden biri değerlendirmeci olarak öğretmenlerdir. Öğretmenlerin ölçek kullanmayla ilgili problem yaşamalarının yanında, değerlendirme yeterlilikleri de ön plana çıkan bir konudur. Sağlıklı bir değerlendirme için öğretmenlerin değerlendirme konusunda yeterli beceriye sahip olması gerekir. Ancak öğretmenlerin söz konusu becerileri ile ilgili alanyazın incelendiğinde önemli sorunlar olduğu görülmektedir. Geleceğin öğretmenleri, öğretmen adaylarının yazılı anlatım becerisi ve değerlendirme konusunda eksikleri olduğu (Arıc1, 2008; Arıcı ve Ungan, 2008; Temizkan, 2008; Bağc1, 2010; Tiryaki ve Kan, 2015; Kan ve Tiryaki, 2015; Coşkun, 2017; Kayabaşı ve Karadağ Yılmaz, 2019) aynı şekilde öğretmenlerin de değerlendirme çalışmalarında eksikleri olduğu; ölçme araçları geliştirme konusunda yetersiz olduğu sonucuna ulaşılan çalışmalara rastlamak mümkündür (Epçaçan ve Erzen, 2008; Karakoç Öztürk, 2014; Şimşek, 2015; Karatay ve Dilekçi, 2019). Bunun en önemli sebeplerinden biri, hizmet içinde ve hizmet öncesinde konuyla ilgili eğitimlerin yetersiz olmasıdır. Bunu destekler şekilde alanyazında öğretmenlerin hizmet içinde ve hizmet öncesinde yeteri kadar eğitim almadıklarını ifade ettiği çalışmalar bulunmaktadır (Gilbert ve Graham 2010; Yamaç ve Öztürk, 2018; Zorbaz, 2019).

İlkokul kademesi, yazma öğretiminin temellerinin atıldığı bir dönemdir. Bu dönem yazılı anlatım becerisinin geliştiği dönem olmakla birlikte, öğrencilerin yazmaya karşı ilgi, tutum, kaygı vb. duygularının da şekillendiği dönemdir. Bu süreçte hem yazma öğretiminde hem de değerlendirme ve geribildirim konusunda en önemli görev sınıf öğretmenlerine düşmektedir. Bu bağlamda sinıf öğretmenlerinin yazma 
becerisini değerlendirme ölçütleri önem arz etmektedir. Çünkü öğretmenlerin ölçütleri, hem yazma öğretiminin şekillenmesinde hem de öğrencilerin yazmaya ilişkin duyguları üzerinde önemli bir faktördür. Alanyazında öğretmen ve öğretmen adayları ile ilgili yapılmış çalışmalar olmakla birlikte sınıf öğretmenlerinin yazılı anlatımı değerlendirme becerileri konusunda sınırlı sayıda çalışma (Sarikaya ve Yılar, 2018; Yamaç ve Öztürk, 2018) bulunmaktadır. Bu da yazma öğretiminin temelini atan sınıf öğretmenlerinin, hangi değerlendirme ölçütlerini kullandığının bilinmesini önemli kılmaktadır. Buradan hareketle bu çalışmanın amacı, sınıf öğretmenlerinin, öğrenci metinlerini hangi ölçütlere göre değerlendirdiğini ortaya koymaktır. $\mathrm{Bu}$ bağlamda aşağıdaki soruların cevapları aranmıştır:

- Sınıf öğretmenleri hangi yazılı anlatım çalışmalarını yapmaktadır?

- Sınıf öğretmenleri hangi metin türlerinde yazma çalışmaları yapmakta ve çalışmalara ne kadar süre ayırmaktadır?

- Sınıf öğretmenlerinin değerlendirme aşamasında ölçek kullanma durumu nedir?

- Sınıf öğretmenleri, hikâye edici ve bilgilendirici metinleri değerlendirirken hangi ölçütleri kullanmaktadır?

\section{Yöntem}

\section{Araştırma Modeli}

Bu çalışma, nitel araştırma yöntemlerinden durum çalışması deseninde tasarlanmıştır. Durum çalışmaları, belli bir duruma ilişkin sonuçları ortaya koymayı amaçlar. Bu desende, bir duruma ilişkin etkenler (ortam, birey, süreç, olay) bütüncül yaklaşımla araştırılır, ilgili durumu nasıl etkiledikleri ve ilgili durumdan nasıl etkilendikleri üzerinde odaklanılır (Yıldırım ve Şimşek, 2018). Çalışmada ele alınan durum; sınıf öğretmenlerinin ne tür yazılı anlatım çalışmaları yaptığı; hangi metin türlerinde yazma çalışmaları yaptığı ve çalışmalara ne kadar süre ayırdığı; değerlendirme aşamasında ölçek kullanma durumu ile hikâye edici ve bilgilendirici metinleri değerlendirirken kullandığı ölçütlerdir. Bu nedenle 
çalışma, bütüncül tek durum desenli bir durum araştırması olarak tasarlanmıştır.

\section{Çalışma Grubu}

Araştırmanın katılımcıları sınıf öğretmenlerinden oluşmaktadır. Katılımcıların belirlenmesinde amaçlı örneklem yöntemlerinden maksimum çeşitlilik yöntemi kullanılmıştır. Buradaki amaç göreli olarak küçük bir örneklem oluşturmak ve bu örneklemde çalışılan probleme taraf olabilecek bireylerin çeşitliliğini maksimum derecede yansıtmaktır (Yıldırım ve Şimşek, 2018). Farklı koşullarda çalışan öğretmenlerin görüşlerinin yansıtılması örneklem seçiminde etkili olmuştur. Bu amaçla farklı şehir ve sosyoekonomik çevrelerde çalışan öğretmenler seçilerek çeşitlilik sağlanmaya çalışılmıştır. Bu bağlamda araştırmanın katılımcları İstanbul, Şanlıurfa ve Van illerindeki öğretmenlerden oluşmuştur. Araştırmaya katılan öğretmenlere ilişkin bilgiler Tablo 1'de sunulmuştur:

Tablo 1. Katılımcılara ilişkin bilgiler

\begin{tabular}{lll}
\hline Öğretmen bilgileri & & $\mathbf{f}$ \\
\hline Mezuniyet & Eğitim Fakültesi & 35 \\
& Fen Edebiyat Fakültesi & 1 \\
Toplam & 36 \\
Cinsiyet & Kadın & 11 \\
& Erkek & 25 \\
Hizmet yılı & Toplam & 36 \\
& $0-10$ yıl & 11 \\
& $11-20$ yıl & 17 \\
& $21-30$ yıl & 6 \\
& 31 ve üstü & 2 \\
& Toplam & 36 \\
\hline
\end{tabular}

Tablo 1'e göre öğretmenlerin biri hariç, geri kalanı eğitim fakültesi mezunudur. Öğretmenlerin 25'i erkek, 11'i kadındır. Öğretmenlerin deneyimlerine bakıldığında 0-10 yıl arasında 11 kişi, 11-20 yıl arasında 17 kişi, 21-30 yıl arasında 6 kişi ve 31 yıl üzerinde 2 kişi olduğu görülmektedir. Genel olarak bakıldığında katılımcıların deneyimli oldukları görülmektedir. 


\section{Veri Toplama Süreci}

Araştırmada, sınıf öğretmenlerinin konuya ilişkin görüşlerinin belirlenmesi için yarı yapılandırılmış görüşme tekniği kullanılmıştır. Görüşme formunun hazırlanması için önce alanyazın taraması yapılmış ve buna bağlı olarak sorular hazırlanmıştır. Formun iç geçerliliğini sağlamak amacıyla form Türkçe eğitimi ve sınıf öğretmenliği alanında uzman 4 kişinin görüşüne sunulmuştur. Uzmanların önerileri doğrultusunda gerekli düzeltmeler yapılmış ve 2 sınıf öğretmeni ile pilot çalı̧̧ma yapılmıştır. Öğretmenlerle yapılan ön görüşme sonucu formda tespit edilen ifade sıkıntıları giderilmiş ve düzeltmeler yapılarak forma son hali verilmiştir. Bu görüşmeler çalışmaya dâhil edilmemiştir. Görüşme for$\mathrm{mu}$; cinsiyet, mezuniyet durumu, hizmet süresi gibi demografik bilgiler ve araştrıma sorularına yönelik altı sorudan oluşmaktadır. Araştırma soruları baglamında katılımclara yöneltilen sorular Tablo 2'de verilmiştir.

Tablo 2. Görüşme soruları

\begin{tabular}{|c|c|}
\hline Araştırma sorusu & Görüşme sorusu \\
\hline $\begin{array}{l}\text { Sınıf öğretmenleri hangi yazılı } \\
\text { anlatım çalışmalarını yapmak- } \\
\text { tadır? }\end{array}$ & $\begin{array}{l}\text { Sınıfta yaptığınız yazma çalışmalarına örnek verebilir } \\
\text { misiniz? }\end{array}$ \\
\hline $\begin{array}{l}\text { Sinıf öğretmenleri hangi metin } \\
\text { türlerinde yazma çalışmaları } \\
\text { yapmakta ve çalışmalara ne kadar } \\
\text { süre ayırmaktadır? }\end{array}$ & $\begin{array}{l}\text { Hangi metin türlerinde yazma çalışmaları yapıyorsunuz? } \\
\text { Yazma çalışmalarına haftada kaç ders ayırıyorsunuz? }\end{array}$ \\
\hline $\begin{array}{lrr}\text { Sınıf öğretmenlerinin } & \text { değer- } \\
\text { lendirme aşamasında } & \text { ölçek } \\
\text { kullanma durumu nedir? } & \\
\end{array}$ & $\begin{array}{l}\text { Öğrencilerinizin metinlerini değerlendirirken herhangi } \\
\text { bir ölçek kullanıyor musunuz? (Kullanıyorsanız lütfen } \\
\text { nasıl bir ölçek olduğu ile ilgili açıklama yapınız) }\end{array}$ \\
\hline $\begin{array}{l}\text { Sinıf öğretmenleri, hikâye edici ve } \\
\text { bilgilendirici metinleri değer- } \\
\text { lendirirken hangi ölçütleri } \\
\text { kullanmaktadır? }\end{array}$ & $\begin{array}{l}\text { Öğrencilerinizin yazdığı hikâye edici metinleri değer- } \\
\text { lendirirken hangi özelliklere dikkat ediyorsunuz? } \\
\text { Öğrencilerinizin yazdığı bilgilendirici metinleri değer- } \\
\text { lendirirken hangi özelliklere dikkat ediyorsunuz? }\end{array}$ \\
\hline
\end{tabular}

Covid-19 salgını nedeniyle veriler uzaktan görüşme şeklinde toplanmıştır. Form, elektronik ortamda hazırlanarak, belirlenen öğretmenlere çevrimiçi olarak gönderilmiştir. Katılımcılar formu doldurup araştırmacılara göndermiştir. Katılımcılardan gelen cevaplar incelenmiş 
bazı katılımclara yeterince açık olmayan cevaplar için dönüş yapılmış ve söz konusu sorularla ilgili tekrar görüş alınmıştır.

\section{Veri Analizi}

Çalışmanın verileri betimsel analiz tekniği ile çözümlenmiştir. Elde edilen veriler kontrol edilerek, eksik soru olup olmadığına bakılmış ve 36 öğretmenin de bütün sorulara cevap verdiği belirlenmiştir. Katılımcılara Ö1, Ö2, Ö3... şeklinde kod isimler verilerek, her bir soruya ait cevaplar bir araya getirilmiş ve analizler yapılmıştır. Önce konuşmalardan kesitler alınmış, kesitlere göre kodlar belirlenmiştir. Kesit ve kod belirleme aşamasında iki araştırmacı ayrı ayrı çalışmış, daha sonra karşılaştırma yapılırken ihtilaf olan bölümler birlikte ele alınarak uzlaşma sağlanmıştır. Hikâye edici ve bilgilendirici metinler ile ilgili bölümün tema-kategori ilişkisi, Özbay (1995), Demirel (1999) ve Bağcı (2007)'nın yazılı anlatım çalışmalarını değerlendirme amacıyla hazırladıkları ölçeklerden yararlanarak Temizkan (2008) tarafından hazırlanan "Bilgilendirici ve Öyküleyici Metinleri Değerlendirme Formu" na göre yapılmıştır. Toplam 33 maddeden oluşan form, bilgilendirici ve öyküleyici metinleri dış yapı, içyapı, dil ve anlatım özellikleri bakımından değerlendirebilmek üzere yapılandırılmıştır.

\section{Araştırmanın geçerlik ve güvenirliği}

Nitel araştırmalarda geçerlik ve güvenirlik; inandırıcılık, aktarılabilirlik, tutarlılık ve teyit edilebilirlik kavramlarıyla açıklanmaktadır. İnandırıcılığını artırmak için bulgular kısmında tema, kategori ve kod tablosu oluşturulmuş, kodların frekans değeri ve karşılık gelen örnek öğretmen görüşleri tek tabloda sunulmuştur. Aktarılabilirlik özelliğini artırmak için çalışmanın yöntem kısmı açık, anlaşılır ve detaylı bir şekilde verilerek; veri toplama araçları, veri toplama süreci ve analiz süreci ayrıntılı bir şekilde okuyucuya ve diğer araştırmacılara sunulmuştur. Verilerin analizinde iki araştırmacı ayrı ayrı kodlama yapmış ve kodlayıcılar arasindaki tutarlılığa bakılmıştır. Öğretmen görüşleri alanyazınla uyumlu olarak sınıflandırılmıştır. Teyit edilebilirlik için çalışma notları ve katılımcı görüşlerini içeren form muhafaza edilmektedir. 


\section{Etik Kurul}

Bu çalışma için Hacettepe Üniversitesi Etik Kurulundan 24.11.2020 tarih ve 35853172-300 sayılı etik kurul kararı ile çalışmanın yapılmasının uygun olduğu kararı alınmıştır.

\section{Bulgular}

Bu bölümde çalışmanın sonucunda elde edilen bulgular yer almaktadır. Araştırma bulguları, araştırma soruları dikkate alınarak sıralanmış, frekans tabloları ve öğretmen cevapları verilmiştir. Öğretmen görüşlerinden kesitler verilirken örneklemi en iyi temsil eden ve en fazla sayıda tekrar eden cevapların verilmesine dikkat edilmiştir.

Araştırmanın birinci alt problemi olan "Sınıf öğretmenleri hangi yazılı anlatım çalışmalarını yapmaktadır?" sorusuna yönelik öğretmenlerin ne tür çalışma yatıkları ile ilgili verdiği cevapları Tablo 3'teki gibidir:

Tablo 3. Öğretmenlerin sınıftaki yazma çalışmalan

\begin{tabular}{|c|c|c|}
\hline Çalışma türü & $\mathrm{f}$ & Öğretmen cevapları \\
\hline Hikâye tamamlama & 10 & $\begin{array}{l}\text { Ö1: Bazen kendi kafamdan geçen bir hikâyenin (bu o gün yaşadığımız } \\
\text { bir olay da olabiliyor ya da tamamen hayal ürünü bir hikâye) başın } \\
\text { ben yazdırı sonunu çocukların kendi hayal güçleriyle getirmelerini } \\
\text { istiyorum. Ö7:Giriş bölümünü benim tarafında yapılan bir hikâyenin } \\
\text { devamını yazdırlması gibi... Yarım hikâye tamamlama } \\
\text { Ö17:Okuduğumuz bitirmediğimiz bir öykü ya da masalın devamın } \\
\text { yazmak. }\end{array}$ \\
\hline Serbest yazma & 5 & $\begin{array}{l}\text { Ö4:Herhangi bir olay ile ilgili hikâye edici metin çalışması. } \\
\text { Serbest hikâye yazma vb. Ö21:Serbest yazma çalışması (tabi konu } \\
\text { önemli) }\end{array}$ \\
\hline Konu verip yazdırma & 5 & $\begin{array}{l}\text { Ö3:Bir ilin genel özellikleri... Ö5:Konu verip kompozisyon } \\
\text { çalışmast... Ö14:Belirli gün ve haftalarla ilgili metin ve şiir } \\
\text { çalı̧̧maları... }\end{array}$ \\
\hline Anı yazmak & 3 & $\begin{array}{l}\text { Ö17:Bir anımızı yazmak... Ö13:Başından geçen en mutlu olay, en } \\
\text { korktuğu anısı kendine özgü hikâye yazımı... }\end{array}$ \\
\hline Görsel verip yazdırma & 3 & $\begin{array}{l}\text { Ö5:Bir resim ya da fotoğraf verip ona uygun bir hikâye yazmaların } \\
\text { isteme... Ö33:Verilen resimler arasında bağ kurarak hikâye yazmak. }\end{array}$ \\
\hline Anahtar kelimeler verme & 2 & $\begin{array}{l}\text { Ö1:Bazen de onlara 5, } 6 \text { kelime verip bu kelimeleri kullanarak bir } \\
\text { hikâye yazmalarm istiyorum. Ö15:Anahtar kelimelerle metin } \\
\text { yazma... }\end{array}$ \\
\hline Konu belirleme (birlikte) & 2 & $\begin{array}{l}\text { Ö8:Örneğin sınıf̧̧a bir konu tespiti yaptıktan sonra bazen bu ko- } \\
\text { nunun giriş kısmın sınıf̧a belirleyip... Ö33:Merak edilen, güncel } \\
\text { olaylar, önemli kişiler hakkında bilgi toplamak. }\end{array}$ \\
\hline Günlük & 1 & Ö17:Günlük yazmak... \\
\hline Özetleme & 1 & Ö15:Araştırdlğı bir konuyu özetleme. \\
\hline Yaratıcı yazma & 1 & $\begin{array}{l}\text { Ö24:Önce hayal kurmalarını sonra ise hayali kâğıda dökmelerini } \\
\text { istiyorum. }\end{array}$ \\
\hline
\end{tabular}


Tablo 3'e göre öğretmenler çoğunlukla hikâye tamamlama çalışması yapmaktadır. Ardından en fazla yapılan çalışmalar, serbest yazma ve konu verip yazdırma şeklinde olmuştur.

Araştırmanın ikinci alt problemi olan "Sınıf öğretmenleri hangi metin türlerinde yazma çalışmaları yapmakta ve çalışmalara ne kadar süre ayırmaktadır?" sorusuna yönelik olarak öğretmenlerin hangi metin türlerinde yazma çalışmaları yaptığıyla ilgili verdiği cevaplar Tablo 4'teki gibidir:

Tablo 4. Öğretmenlerin yazma çalışmalarında kullandığı metin türleri

\begin{tabular}{ll}
\hline Metin türü & f \\
\hline Hikâye edici metin & 24 \\
Bilgilendirici metin & 13 \\
Şiir & 11 \\
Toplam & 48 \\
\hline
\end{tabular}

Tablo 4'e bakıldığında öğretmenlerin yazma çalışmalarında önemli ölçüde hikâye edici metinleri kullandığı görülmektedir. Bunu bilgilendirici metin ve şiir türlerine yönelik çalışmalar takip etmektedir. Toplam değerin 48 olması (katılımcı sayısından fazla olması) öğretmenlerin birden fazla metin türünü tercih etmesiyle ilgilidir.

İkinci alt problem kapsamında öğretmenlerin yazma çalışmalarına haftada ne kadar süre ayırdığ 1 ile ilgili verdiği cevaplar Tablo 5'teki gibidir:

Tablo 5. Öğretmenlerin yazma çalışmalarına ayırdığı süre

\begin{tabular}{ll}
\hline Süre (Haftalı) & f \\
\hline Hiç ayırmiyorum & 0 \\
1-2 ders & 13 \\
3-4 ders & 17 \\
5 dersten fazla & 6 \\
Toplam & 36 \\
\hline
\end{tabular}

Tablo 5'e göre öğretmenlerin tamamı her hafta yazma çalışmalarına zaman ayırmaktadır. Öğretmenlerin önemli bir kısmı haftada 3-4 saat zaman ayırdığını ifade etmiştir. Ardından, 1-2 saat zaman ayırıyorum diyen öğretmen sayısı da oldukça fazladır. 
Araştrımanın üçüncü alt problemi olan "Sınıf öğretmenlerinin değerlendirme aşamasında ölçek kullanma durumu nedir?" sorusuna yönelik öğretmenlerin verdiği cevaplar Tablo 6'daki gibidir.

Tablo 6. Öğretmenlerin ölçek kullanma durumu

\begin{tabular}{|c|c|c|}
\hline Ölçek kullanma durumu & f & Katılımcı cevaplart \\
\hline $\begin{array}{l}\text { Ölçek } \\
\text { Kullananlar }\end{array}$ & 7 & $\begin{array}{l}\text { Ö5: Performans değerlendirme ölçütleri. Ö12:Kazanım } \\
\text { değerlendirme ölçeğini kullanırım. Ö19:Yazma becerisi } \\
\text { değerlendirme ölçeği. Ö22: Rubrik, akran ve öz değer- } \\
\text { lendirmeler kullanıyorum }\end{array}$ \\
\hline $\begin{array}{l}\text { Ölçek } \\
\text { Kullanmayanlar }\end{array}$ & 29 & $\begin{array}{l}\text { Ö25:Ölçek kullanmıyorum Ö26:Herhangi bir ölçek } \\
\text { kullanmıyorum. Ö10:Sabit ve standart bir ölçek kullan- } \\
\text { mıyorum. Ö16:Belirli bir ölçek yok yazı yazma kurallarına } \\
\text { göre değerlendiriyorum... Ö18:Sınııı düzeyine göre } \\
\text { değerlendirme yapıyorum. Standart ölçek kullanamıyo- } \\
\text { rum. Ö31:Standart bir ölçek kullandı̆̆ım söyleyemem. } \\
\text { Ancak bir önceki soruda geçen } 6 \text { ölçütü bir ölçek gibi } \\
\text { kabul edersek ben o ölçeğe göre değerlendiriyorum. }\end{array}$ \\
\hline
\end{tabular}

Öğretmenlerin büyük çoğunluğu (\%80,5) standart bir ölçme aracı kullanmadığını, bunun yerine kendi değerlendirme ölçütlerine göre değerlendirme yaptığını ifade etmiştir. "Standart ölçme aracı kullanıyorum" diyen öğretmenler ise performans değerlendirme, kazanım değerlendirme, yazma becerisi değerlendirme, rubrik, akran ve öz değerlendirme, klasik değerlendirme ve yazma değerlendirme ölçeklerini kulland1ğını ifade etmiştir.

Araştırmanın dördüncü alt problemi olan "Sınıf öğretmenleri, hikâye edici ve bilgilendirici metinleri değerlendirirken hangi ölçütleri kullanmaktadır?" sorusu kapsamında öğretmenlerin hikâye edici metinleri değerdirme ölçütlerine yönelik verdiği cevaplar Tablo 7'deki gibidir.

Tabloya göre, öğretmenler hikâye edici metinleri değerlendirirken metin dış yapısı ile ilgili en fazla kâğıt düzenine; dil ve anlatım kategorisinde de en fazla yazım kuralları ve noktalama işretlerine, kendini ifade etme becerisine ve cümle yapısına dikkat etmektedir. İçerik kategorisinde ise en fazla metin bütünlüğü, hikâye karakterleri- kahramanları, olayların oluş sırası, metnin bölümleri (giriş, gelişme, sonuç) ve hikâyenin mesajına dikkat edildiği görülmektedir. 
Tablo 7. Öğretmenlerin hikâye edici metinleri değerlendirme ölçütleri

\begin{tabular}{|c|c|c|c|}
\hline Kategoriler & Kodlar & $\mathrm{f}$ & Katılimci cevaplart \\
\hline \multirow[t]{2}{*}{ Dış yapı } & Kâğıt düzeni & 11 & $\begin{array}{l}\text { Ö8:Satırlar ve kelimeler arasında bulunması gereken uygun boşluğun bırakıl- } \\
\text { ması... Ö31:Defter veya kâğıt düzenine... Ö16:Harfler ve kelimeler arasındaki } \\
\text { uygun mesafenin olması. }\end{array}$ \\
\hline & Okunaklılık & 3 & $\begin{array}{l}\text { Ö7:Okunaklı yazllıp yazılmadığı. Çünkü başkası tarafından da okunduğunda } \\
\text { akıcı bir şekilde okunabilmeli diyorum. Ö8:Harflerin düzgün ve okunaklı yazıl- } \\
\text { ması. }\end{array}$ \\
\hline \multirow{7}{*}{$\begin{array}{l}\text { Dil ve } \\
\text { Anlatım }\end{array}$} & $\begin{array}{l}\text { Yazım ve } \\
\text { noktalama }\end{array}$ & 15 & $\begin{array}{l}\text { Ö2:Yazım ve noktalama kuralları. Ö22:Metinlerde anlaml ve dilbilgisi ku- } \\
\text { rallarına uygunluk... Ö11: Noktalama işaretlerine uyulup uyulmadığı... Ö4: } \\
\text { İmla ve noktalama kurallarna uyulmuş mu? Ö8: Noktalama işaretleri ve yazım } \\
\text { kurallarna dikkat edilerek metin oluşturmalarına özen gösteririm. }\end{array}$ \\
\hline & $\begin{array}{l}\text { Kendini ifade } \\
\text { etme }\end{array}$ & 10 & $\begin{array}{l}\text { Ö18:Anlatmak istediklerini yazıya aktarıp aktarmadı̆̆ına bakarım. Ö20:Bu } \\
\text { öğrencimi ne kadar yansttıyor. Ö11:Anlatmak istediklerini ne tür cümlelerle ve } \\
\text { nasıl anlattığı (mecazi ya da gerçek) }\end{array}$ \\
\hline & Cümle yapısı & 7 & $\begin{array}{l}\text { Ö8:Doğru ve kurall cümleler kurabilme... Ö11:Cümlelerin kurallı olup olma- } \\
\text { yışı... Ö24: Cümleler kurallı mı? }\end{array}$ \\
\hline & $\begin{array}{l}\text { Kelime } \\
\text { kullanımı }\end{array}$ & 5 & $\begin{array}{l}\text { Ö8: Cümleyi oluşturan kelimelerin doğru yerde ve anlamlarına uygun olarak } \\
\text { kullanılmaları. Ö26:Doğru kelimeleri kullanmast. Ö29:Kelime kullanımı. }\end{array}$ \\
\hline & Anlatım & 3 & $\begin{array}{l}\text { Ö30: Anlatım. Ö7:Hikâye edici metinleri değerlendirirken öncelikle anlatım } \\
\text { becerisi }\end{array}$ \\
\hline & Akıcılık & 2 & Ö9:Akıcılık. Ö10: Akıcılık \\
\hline & Anlaşılırlık & 2 & $\begin{array}{l}\text { Ö18: Yazının anlaşılır olup olmadığına bakarım. Ö33: Açık ve anlaşıllı ol- } \\
\text { masına... }\end{array}$ \\
\hline \multirow{15}{*}{ İçerik } & Mesaj & 5 & $\begin{array}{l}\text { Ö12: Hikâye ö̆̆̈̈t veriyor mu? Ö20:Bir mesaj veriyor mu? Ö33:Ders ver- } \\
\text { mesine... }\end{array}$ \\
\hline & Bütünlük & 14 & $\begin{array}{l}\text { Ö18:Hikâyedeki anlam bütünlü̆̆̈̈̈ne bakarım. Ö31:Konu dışına çıklmıs mı? } \\
\text { Ö33:Anlam bütünlüğüne. Ö36:Anlam bütünlü̈̆̈̈̈nün olmasına dikkat ederim. }\end{array}$ \\
\hline & $\begin{array}{l}\text { Karakter- } \\
\text { kahraman }\end{array}$ & 9 & $\begin{array}{l}\text { Ö8: Olayın kahramanlarını, geçtiği zamanı, olay yerini net olarak belirleme. Ö12: } \\
\text { Kahramanları özellikleri nelerdir? gibi özelliklere bakarım. Ö31: Hikâye unsur- } \\
\text { ları (yer, zaman, karakter, olay) yer almı̧̧ mı? }\end{array}$ \\
\hline & Oluş sırası & 7 & $\begin{array}{l}\text { Ö14:Olayları oluş sırasına göre yazıyor mu? Ö19:Olayları oluş sırasına göre } \\
\text { yazma Ö11:Olay sıralaması... }\end{array}$ \\
\hline & $\begin{array}{l}\text { Giriş, gelişme, } \\
\text { sonuç }\end{array}$ & 6 & $\begin{array}{l}\text { Ö3:Metinde giriş, gelişme ve sonuç bölümlerine dikkat etmiş mi? Ö6:Giriş, } \\
\text { gelişme, sonuç... Ö31: Hikâyenin bölümleri(giriş, gelişme, sonuç) var mı? }\end{array}$ \\
\hline & Olay örgüsü & 3 & $\begin{array}{l}\text { Ö29: Olay örgüsü. Ö30:Olay kurgusu. Ö31: Hikâye unsurları (yer, zaman, } \\
\text { karakter, olay) yer almış mı? }\end{array}$ \\
\hline & Özgünlük & 6 & $\begin{array}{l}\text { Ö1: Özgün olmasinı. Ö20: Metin özgün mü? Ö36:Öğrencinin kendine özgü } \\
\text { cümleler kurmuş olması. }\end{array}$ \\
\hline & Başlık & 4 & $\begin{array}{l}\text { Ö8:Seçilmiş konuya uygun başlık bulmak.Ö31:Başlık yazmış mı, başlık ve içerik } \\
\text { uyumlu mu? }\end{array}$ \\
\hline & Hayal gücü & 4 & $\begin{array}{l}\text { Ö1:Hayal gücünü bütün genişliğiyle ortaya koyabilmesini. Ö12:Hayal gücünü } \\
\text { kullanmış mı? }\end{array}$ \\
\hline & Metin türü & 3 & $\begin{array}{l}\text { Ö8:Ayrıca, Hikâye Edici türü ortaya koyan özelliklerin metne işlenmesi. } \\
\text { Ö33:Metnin türüne uygunluk. }\end{array}$ \\
\hline & Amaç & 2 & Ö17:Genel olarak yazma amacıyla uyumlu mu? \\
\hline & Ana düşünce & 2 & $\begin{array}{l}\text { Ö8:Ana düşüncenin metinde kendini belli etmesi. Ö15:Ana fikri takip yani } \\
\text { dağılmama. }\end{array}$ \\
\hline & Sonuç & 2 & Ö20:Bir sonuca bağlamış mı? Ö10:Sonuç ya da ana fikir... \\
\hline & Yer & 2 & $\begin{array}{l}\text { Ö8: Olayın kahramanlarını, geçtiği zamanı, olay yerini net olarak belirleme. Ö31: } \\
\text { Hikâye unsurları (yer, zaman, karakter, olay) yer almış mı? }\end{array}$ \\
\hline & Zaman & 2 & $\begin{array}{l}\text { Ö8:Olayın kahramanlarını, geçtĭ̆i zamanı, olay yerini net olarak belirleme. } \\
\text { Ö31:Hikâye unsurları (yer, zaman, karakter, olay) yer almış mı? }\end{array}$ \\
\hline
\end{tabular}




\section{Araştırmanın dördüncü alt problem kapsamında öğretmenlerin bilg-} ilendirici metinleri değerlendirme ölçütlerine yönelik verdiği cevaplar Tablo 8'deki gibidir.

\section{Tablo 8. Öğretmenlerin bilgilendirici metinleri değerlendirme ölçütleri}

\begin{tabular}{|c|c|c|c|}
\hline Kategori & Kodlar & $\mathrm{f}$ & Katılımci cevapları \\
\hline Diş Yapı & $\begin{array}{l}\text { Kâğıt düzeni ve } \\
\text { okunaklık }\end{array}$ & 6 & $\begin{array}{l}\text { Ö8:Sayfa düzenine dikkat edilip edilmediği, satır ve paragraf oluşturma } \\
\text { kurallarına uyulup uyulmadığt... Ö31:Satır arası boşlukları, sayfa } \\
\text { kenarları, çizgiyi kullanma, paragraf başı gibi düzen ile ilgili kurallara } \\
\text { dikkat etmiş mi? }\end{array}$ \\
\hline \multirow[t]{6}{*}{ Dil ve Anlatım } & Yazım ve noktalama & 11 & $\begin{array}{l}\text { Ö21:Öncelik tabiki yazım yanlışı, noktalama...̈̈8: Noktalama işaretleri } \\
\text { ve yazım kurallarına. Gereken özenin gösterilip gösterilmediŏi. } \\
\text { Ö4:Noktalama ve imla kurallarına uyulmuş mu? Yazım kurallarına } \\
\text { uyma. Ö24:İmla ve noktalama işaretlerine uyulmuş mu? Ö13:Yazım, } \\
\text { imla kuralları... Ö31:Noktalama işaretlerini yerinde ve uygun kullanmış } \\
\text { mı? Ö10:Yazım kuralları... }\end{array}$ \\
\hline & Kendini ifade etme & 7 & $\begin{array}{l}\text { Ö1:Bilgilerini yazı diline aktarabilmesi ve kendini rahatlıkla ifade ede- } \\
\text { bilmesi. Ö29: Anlatım. Ö8:Türkçenin etkili bir anlatımla kullanılıp } \\
\text { kullanılmağı... Ö26:Anlatımını uygun ifadelerle yapıp yapmadığı. Ö7: } \\
\text { Verilmek istenen bilginin anlaşılır bir cümle ve cümlelerle yazıllı } \\
\text { yazılmadığı... Ö19:Fikirlerini cümlelere dönüş̧ürme... Ö13:Konunun } \\
\text { net şekilde ifade edilmesi }\end{array}$ \\
\hline & Kelime kullanımı & 5 & $\begin{array}{l}\ddot{3} 3 \text { :Kelime ve kavramları doğru algılamış mı? Ö29: Kelime kullanımı. } \\
\text { Ö19: Sözcükleri kullanma. Ö9: Terimlerin yazımı ve doğru kullanılması. } \\
\text { Ö10:Kavramlar doğru kullanılmış mı? }\end{array}$ \\
\hline & Anlaşılırlık & 4 & $\begin{array}{l}\text { Ö28:Anlaşılır bir dille anlatım. Ö9:Sadelik ve anlaşılabilirlik } \\
\text { Ö33:Anlaşılır olması. }\end{array}$ \\
\hline & Cümle düzeni & 3 & $\begin{array}{l}\text { Ö8:Dilbilgisi kurallarına uygun doğru kelime ve cümlelerin oluşturulup } \\
\text { oluşturulmadığı. Ö19:Anlamlı ve kurall cümleler yazar. Ö25:Cümle } \\
\text { kurma. }\end{array}$ \\
\hline & Akıcılık & 1 & Ö22: Metinler akıcı ve okunabilir şekilde mi? \\
\hline \multirow[t]{8}{*}{ İçerik } & Doğruluk & 9 & $\begin{array}{l}\text { Ö3:Bilgiler doğru mu? 24:Bilgiler doğru ve tutarlı mı? } \\
\text { 30:Bilginin doğruluğu. Ö24:Kaynak belirtilmiş mi? Ö21:Bilgilerin } \\
\text { realitesi.Ö2: Bilgi kontrol edilmiş mi? Ö22:Öğrenci doğru bir bilgiye } \\
\text { dayalı metinler yazmış mı? }\end{array}$ \\
\hline & $\begin{array}{l}\text { Düşünceyi geliştirme } \\
\text { yolları }\end{array}$ & 7 & $\begin{array}{l}\text { Ö12:Günlük yaşantılara örnek verip vermediŏine. Ö14: Bilgileri } \\
\text { somutlaştırıyor mu? Ö4: Günlük yaşantısıyla ilişkilendirilmiş mi? Ö27: } \\
\text { Konu hakkında görsellere yer vermeli. Ö12:Konuyla ilgili örnek vermiş } \\
\text { mi? }\end{array}$ \\
\hline & Araştırma & 6 & $\begin{array}{l}\text { Ö20:Araştırma yapmış mı? Ö30: Bilginin araştıılma şekli. } \\
\text { Ö5: Konuyu araştırmış mı? }\end{array}$ \\
\hline & Bütünlük & 5 & $\begin{array}{l}\text { Ö20: Metindeki cümleler konuyla ilgili mi? Ö18: Bilgi verirken anlam } \\
\text { bütünlü̆̈̈̈nü koruyup korumadığına... Ö5: Konudan uzaklaşmadan } \\
\text { anlatılmak istenileni anlatıp anlatmadığına dikkat ederim. }\end{array}$ \\
\hline & Metin türü & 4 & $\begin{array}{l}\text { Ö6: Bilgilendirici metin mi ona dikkat ederim. Ö8:Yazılmış olan metin } \\
\text { türünü belirten özelliklerin metne yansıtıllp yansıtılmadı̆̆ı... } \\
\text { Ö33:Metnin türüne uygunluk. }\end{array}$ \\
\hline & Özgünlük & 4 & $\begin{array}{l}\text { Ö2:Konuya dair özgün fikri var mı? Ö15:Kendi mi yazmış bir büyü̈̆̈̈̈n- } \\
\text { den mi yardım almış? Kendi cümleleri ile yazmış olmak. }\end{array}$ \\
\hline & Amaç & 3 & $\begin{array}{l}\text { Ö34: Metnin içeriğinin amaca hizmet edip etmediğine... } \\
\text { Ö19:Yazma amacı belirleme. }\end{array}$ \\
\hline & Başlık & 3 & $\begin{array}{l}\text { Ö8: Konunun içeriğine uygun bir başlık seçilip seçilmediği... } \\
\text { Ö31: Başlık, maddeler halinde yazma, işaret veya işlemleri düzgün ve } \\
\text { yerinde kullanmış mı? }\end{array}$ \\
\hline
\end{tabular}




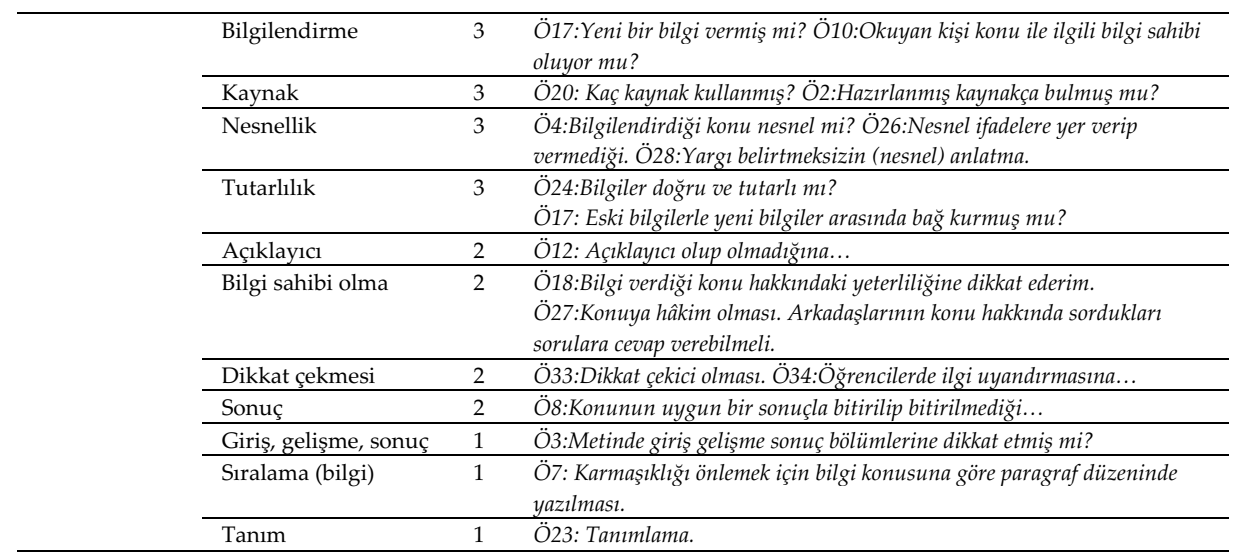

Tabloya göre öğretmenler bilgilendirici metinleri değerlendirirken metin diş yapısı kategorisinde en fazla kâğıt düzeni ve okunaklığa dikkat ederken; dil ve anlatım kategorisinde en fazla yazım kuralları ve noktalama işaretleri, kendini ifade etme ve kelimelerin doğru kullanımına dikkat etmektedir. İçerik kategorisinde ise en fazla bilgilerin doğruluğu, düşünceyi geliştirme yolları, konuyu araştırma ve metin bütünlüğüne dikkat ettiği görülmektedir.

\section{Tartışma ve Sonuç}

$\mathrm{Bu}$ bölümde öğretmenlerin ifade ettiği ölçütler bağlaminda sonuçlar değerlendirilmiş ve tartışılmıştır. Yazılı anlatım çalışmalarında öğretmenlerin yazılı anlatımı değerlendirme ölçütleri; yazma eğitimi, yazılı anlamı değerlendirme ve geribildirim konusunda önemli ipuçları vermektedir. Bu nedenle öğretmenlerin hangi ölçütlere göre öğrenci metinlerini değerlendirdiği önemlidir.

Çalışmada elde edilen bulgulara göre öğretmenler çoğunlukla hikâye tamamlama çalışması yapmaktadır. Ardından en fazla yapılan çalışmalar, serbest yazma ve konu verip yazdırma şeklinde olmuştur. Bu sonuç alanyazınla büyük oranda örtüşmektedir. Öğretmenlerin çoğunlukla hikâye-metin tamamlama, not tutma, serbest yazma, anahtar kelimelerle çalışma, görsellerden yararlanma vb. çalışmaları kullandığı sonucuna ulaşan çalışmalar mevcuttur (Şimşek, 2015; Karakoç-Öztürk, 2016; Yamaç ve Öztürk, 2018). Öğretmenlerin çoğunlukla hikâye tamamlama, 
serbest yazma, konu verip yazdırma çalışmalarını tercih etmelerinin, öğretmenin yazma amac1, değerlendirme becerisi ve yöntemleriyle ilgili olduğunu düşündürmektedir. Zira bu çalışmalar, öğrencinin yazma becerisini geliştirmekten ziyade yazma düzeyini ortaya koymaya yönelik olabilir. Ayrıca öğretmenler ürün odaklı değerlendirme yaptıklarından ve değerlendirilmeleri daha çok kendi ölçütlerine göre yaptıklarından yüzeysel bir değerlendirmeyle bu işi tamamlamış olacaklardır. Bu nedenle öğretmenlerin, süreç temelli yazma ve değerlendirme çalışmalarından öte kısa süreli ve hemen sonuç alınacak çalışmalara yönlendikleri düşünülmektedir. Oysa öğrencilerin; yazma amacını belirlediği, metin türünü seçtiği, taslak hazırladığı, yazdığı ve düzeltme yaptığı; ayrıca öğretmen tarafından değerlendirme yapılarak kendisine geribildirim sağlandığı, daha uzun ve daha planlı yazma çalışmalarına ihtiyacı vardır. Bu da öğretmenlerin yazma becerisi geliştirme yeterliklerine bağl1dır. Öğretmenlerin yazma becerisi ile ilgili algıları ve yeterlikleri değiştiğinde yazma çalışmalarının niteliğinin de değişeceği bir gerçektir.

Çalışmada ulaşılan bir diğer sonuç öğretmenlerin yazma çalışmalarında çoğunlukla hikâye edici metin yazma çalışmalarına yer vermesidir. Daha önce yapılan çalışmalar da bu sonuçla uyumludur (Cutler ve Graham, 2008; Yamaç ve Öztürk, 2018). Hikâye edici metin türünün öğretmenler tarafından tercih edilmesinin nedeni, hikâyelerin öğrenciler tarafından ilgi çekici bulunmasıdır. Nitekim yapılan çalışmalarda öğrencilerin hikâye edici metinleri ilgi çekici buldukları sonucuna ulaşılmıştır (Karakoç-Öztürk 2016; Coşkun, 2005). Öğrencilerin hikâye edici metin türlerini ilgi çekici bulması; diğer metin türlerine göre daha kolay anlaşılması, daha kolay yazılması ve öğrencilerin bu tür metinlere aşina olmalarıyla ilgidir. Bu da öğretmenlerin hikâye edici metinleri daha fazla tercih etmesinin nedenlerinden biri olabilir. İlkokul öğrencileri için bilgilendirici türde ve şiir türünde yazmak, hikâye edici metinlere göre daha zor olabilir. Ancak öğrencilerin her metin türünden yazma çalışması yapması yazma becerisinin gelişimi adına oldukça önemlidir. Öğrencilerin yazma amacı belirleme, yazma stratejisi kullanma, yazma öncesi, sırası ve sonrasında yapacağı çalışmalar ile gözden geçirme gibi süreçlerde metin türüne özgü becerilerinin gelişimine katkı sağlayacaktır. Öğretmenlerin farklı metin türünde yazma çalışmaları yapabilmesi için her metin türünün özelliklerini ve öğretimini de bilmesi gerekir. Bu 
nedenle öğretmenlerin, farklı metin türlerinde yazma öğretimi yapması için bu konuda desteklenmesi gerekir.

Çalışmada elde edilen bulgulara göre öğretmenlerin tamamı her hafta yazma çalışmalarına zaman ayırmaktadır. Öğretmenlerin çoğunluğu yazma çalışmalarına 1-2 saat ile 3-4 saat zaman ayırdıklarını ifade etmektedir. Önceki çalışmalarda Brindle, Graham, Harris ve Hebert (2015) öğretmenlerin günde 15 dakika yazı öğretmeye ve 25 dakika yazdırmaya ayırdığını; Şimşek (2015) öğretmenlerin yazma öğretimine 27 dakika, yazdırmaya 23 dakika ayırdığını; Yamaç ve Öztürk (2018) ise öğretmenlerin yazma ve yazma öğretimine günde ortalama 50 dakika ayırdığını ifade etmektedir. Graham ve diğ. (2012) 30 dakikası öğretim, 30 dakikası uygulama olmak üzere yazma ve yazma öğretimine günde en az 60 dakika zaman harcanması gerektiğini ifade etmektedir. Buna göre öğretmenlerin yazma çalışmalarına yeteri kadar zaman ayırmadığı sonucuna ulaşılabilir. Bunun en önemli nedeninin ülkemizde sınıfların kalabalıkl1ğıyla ilgili olduğu düşünülmektedir. Etkili yazma çalışması için yazma süreci kadar iyi bir hazırlık, değerlendirme ve geribildirim gerekmektedir. Bunu kalabalık sınıflarda yapmak oldukça zordur. Buna bağlı olarak öğretmenler, daha çok ürün odaklı çalışmaları tercih edip (Başar ve Yavaşlı, 2020) yazmayı bir çırpıda olup biten bir sürece sıkıştırmaktadır. Değerlendirmeyi de yüzeysel yapmaktadır. Bu nedenle öğretmenlerin yazma öğretimine ve yazma çalışmalarına daha fazla zaman ayıracağı koşulların sağlanması gerekmektedir.

Çalışmada elde edilen bir diğer sonuca göre, öğretmenlerin çoğunluğu standart bir ölçme aracı kullanmamakta, bunun yerine kendi ölçütlerine göre değerlendirme yapmaktadır. Benzer şekilde öğretmenlerin standart ölçme aracı kullanmadıkları ve genellikle kendi ölçütlerine göre değerlendirme yaptıkları sonucuna ulaşan çok sayıda çalışma mevcuttur (Temizkan, 2003; Gelbal ve Kelecioğlu, 2007; TED, 2009; Göçer, 2011; Benzer ve Eldem, 2012; Karakoç-Öztürk, 2014; Elma ve Bütün, 2015; Karakoç-Öztürk 2016; Sarikaya ve Yılar, 2018; Karatay ve Dilekçi, 2019; Doğan Kahtalı ve Çelik, 2020). Öğretmenlerin standart ölçme aracı kullanmaması, yapılan değerlendirme çalışmalarını da amacının dışına çıkarmaktadır. Çünkü standart bir ölçek olmadığında öğretmenler genel bir izlenimle çalışmaları değerlendirmekte ve öğrenciye geribildirim vermektedir. İzlenime dayalı değerlendirme öğretmenlerin, öğrencilerin 
yazılarındaki belli unsurları öne çıarmalarına, bunun sonucunda da objektif olmayan bir puanlamaya sebep olmaktadır (Zorbaz, 2013). Öğretmenlerin yazılı anlatımda yazıların daha çok görünüşüne yönelik değerlendirme yapmalarının altındaki en önemli sebeplerden biri de budur. Çünkü öğretmen herhangi bir ölçek olmadan kâğıdı eline aldığında; kâğıt düzeni, harflerin okunaklığı, yazım ve noktalama işaretleri gibi unsurlar daha erken fark edilecektir. Buraya doğru bir yönelim, objektif olmayan bir değerlendirmeye ve yazma becerisini geliştirmeyen bir sürece götürecektir. Öğretmenlerin standart ölçme araçları kullanmamasının altında yatan nedenlerden en önemlisi, ölçeklerle ilgi yaşadıkları sorunlarla ilgilidir. Çünkü öğretmenlerin; öğrenci ürünlerini ölçme ve değerlendirmeye yönelik araçları geliştirme ile mevcut araçları kullanma konusunda önemli eksiklerinin olduğu belirtilmektedir (Epçaçan ve Erzen, 2008; Uygun ve Katrancı 2013). Ölçme aracı geliştiremeyen veya geliştirilmiş ölçme araçlarını kullanmasını bilmeyen öğretmenlerin standart ölçme araçlarını kullanması beklenemez. Bu nedenle öğretmen eğitiminde ve hizmet içinde ölçek kullanımı konusunda öğretmenlerin yetiştirilmesinin, standart ölçme araçlarının kullanımını arttıracağı gibi buna bağlı olarak objektif değerlendirme yapılmasını da sağlayacağı düşünülmektedir.

Metin türlerine göre değerlendirme ölçütlerine bakıldığında, öğretmenlerin hikâye edici metinleri değerlendirirken en fazla kâğıt düzeni, yazım kuralları ve noktalama işaretleri, kendini ifade etme becerisi, cümle yapısı, metin bütünlügü, hikâye karakterleri-kahramanları, olayların oluş sırası, metnin bölümleri (giriş, gelişme, sonuç) ve hikâyenin mesaj1na dikkat edildiği görülmektedir. Bu sonuçlar daha önce yapılan çalışmalarla (Özbay, 2003'ten akt. Zorbaz, 2013; Göçer,2011; Karakoç Öztürk, 2014; Lucero, Fernández ve Montanero, 2018; Sarikaya ve Yilar,2018) büyük oranda örtüşmekle birlikte bunlardan ayrilan noktalar da mevcuttur. Örneğin önceki çalışmalarda elde edilen, anlam bütünlüğüne fazla önem verilmediği (Göçer, 2011; Sarikaya ve Yılar, 2018) sonucunun aksine bu çalışmada öğretmenlerin büyük oranda olmasa da metinde anlam bütünlüğüne dikkat ettiği görülmektedir. Ancak hikâye elementlerinden olan olayın zamanı ve mekânı, ana ve yardımcı karakterler, başlangıç olayı/başlatıcı olay, problem, girişim, sonuç, ana fikir ve tepki unsurlarından (Coşkun, 2014; Akyol, 2019; Güneş, 2019) kahramanlar- 
karakterler unsuruna kısmen yer verildiği diğer unsurların yok denecek kadar az olduğu görülmektedir. Hatta öğretmenler bu unsurların bazılarına hiç değinmemiştir. Ayrıca Temizkan (2008)'ın işaret ettiği, metne uygun başlık konması, düşüncelerin mantıklı bir şekilde sıralanması, yardımcı fikirlere yer verme, neden-sonuç ilişkilerine yer verme, metin türünün özelliklerini yansıtma, paragraf özellikleri, akıcı bir anlatım kullanma, anlatım bozuklukları vb. unsurlara önem verilmediği görülmektedir. Bu sonuç, öğretmenlerin hikâye edici metinleri değerlendirme konusunda yeterli düzeyde olmadığını göstermektedir. Alanyazında öğretmenlerin (Epçaçan ve Erzen, 2008; Karakoç Öztürk, 2014; Şimşek, 2015; Karatay ve Dilekçi, 2019) ve öğretmen adaylarının (Arıcı 2008; Arıc1 ve Ungan, 2008; Temizkan, 2008; Bağcl, 2010; Tiryaki ve Kan, 2015; Kan ve Tiryaki, 2015; Coşkun, 2017; Kayabaşı ve Karadağ Yılmaz, 2019) hem yazılı anlatım becerisinde hem de yazılı anlatımı değerlendirme konusunda birtakım sorunları olduğu belirtilmektedir. Öğretmenler ve öğretmen adaylarının yazılı anlatımda ve öğrenci metinlerini değerlendirmede eksikliklerinin olması akla şu soruları getirmektedir: Kendisi yazarken sorun yaşayan bir öğretmen, öğrencilere nasıl yazmayı öğretecek? Öğrenci metnini değerlendiremeyen öğretmen, öğrenciye nasıl geribildirim verecek ve eksikliklerini gösterecek? Öğretmenler ve öğretmen adaylarının değerlendirme ölçütlerinin yeterli olmamasının altında yatan en önemli sebebin hizmet içinde ve hizmet öncesinde konuyla ilgili eğitimlerin yetersizliğiyle ilgili olduğu düşünülmektedir. Zira yapılan çalışmalar da bu ihtiyacın olduğunu belirtmektedir (Yamaç ve Öztürk, 2018; Gilbert ve Graham, 2010; Zorbaz, 2019). İyi bir yazma eğitimi almış ve kendisi de yazabilen öğretmenler, öğrencilerinin yazma beceresini geliştirmekte daha başarılı olacaktır.

Öğretmenlerin bilgilendirici metinleri değerlendirirken en fazla kâğıt düzeni ve okunaklılık, yazım kuralları ve noktalama işaretleri, kendini ifade etme, kelimelerin doğru kullanımı, bilgilerin doğruluğu, düşünceyi geliştirme yolları, konuyu araştırma ve metin bütünlüğüne dikkat ettiği görülmektedir. Genel olarak bakıldığında öğretmenlerin bilgilendirici metin konusunda ciddi eksikliklerinin olduğu söylenebilir. Öğretmenlerin verdiği cevapların frekans tablosuna bakıldığında her ne kadar bilgilendirici metinlerde olması gereken bazı özellikler belirtilmişse de bu özelliklerin tekrarlanma sıklığı oldukça düşüktür. Ayrıca öğretmenlerin, 
Temizkan (2008)'ın bilgilendirici metinlerde olması gereken özellikler olarak ifade ettiği; konuya uygun başlık kullanma, giriş bölümünde konuyu ortaya koyma, konunun sınırlarını belirleme, gelişme bölümünde ayrıntıları ortaya koyma, konuyla ilgili orijinal buluşlara yer verme, ana düşünceye yer verme, doğru ve tutarlı bilgi verme, yardımcı fikirlere yer verme, yazıdaki düşünceleri savunan kanıtlara yer verme, neden-sonuç ilişkileri kurma, metin türünün özelliklerini yansıtma, paragraf düzenini sağlama, gereksiz tekrarlardan kaçınma, konuya karşı belirgin bir bakış açısı geliştirme ve sonucu yazma gibi unsurlara neredeyse hiç değinilmediği görülmektedir. Bu da öğretmenlerin bilgilendirici metin türünde sağlıklı bir değerlendirme yapamadığını göstermektedir. Bunun nedenleri arasında öğretmenlerin bilgilendirici metin türünün özellikleri hakkında yeterli bilgiye sahip olmadığ 1 şeklinde yorumlanmıştır.

Sonuç olarak, sınıf öğretmenlerinin, öğrencilerin yazılı anlatımlarını değerlendirme konusunda önemli eksiklikleri bulunmaktadır. Öğretmenlerin, objektifliği ve sağliklı değerlendirmeyi sağlayacak standart ölçme araçlarının yerine kendi belirledikleri ölçütleri kullanması, yazmaya yeterince zaman ayırmaması, yazma çeşitliği sağlayamaması önemli bir sorunlardır. Bu çalışmada tespit edilen en önemli sonuçlardan biri öğretmenlerin değerlendirme ölçütlerinin yeterli düzeyde olmamasıdır. Her ne kadar öğretmenler bilimsel araştırmalar sonucu elde edilen değerlendirme ölçütlerinden bazılarını ifade etmişse de bunların frekansları oldukça düşüktür. Sadece birkaç ölçüt (yazım ve noktalama işaretleri, metin bütünlüğü, kâğıt düzeni ve kendini ifade etme) öğretmenlerin yarısı veya daha fazlası tarafından ifade edilirken birçok ölçütte bu sayı 2-3'e kadar düşmektedir. Hatta birçok ölçütün adı bile geçmemektedir. Bu durumun öğretmenlerin, yazılı anlatımı değerlendirmede yeterli düzeyde olmamasının önemli bir göstergesi olduğu düşünülmektedir. Yazma öğretimine yeteri zamanı ayırmayan, yazma çeşitliliği sağlamayan, öznel değerlendirme yapan ve yazılı anlatımı değerlendirme ölçütleri konusunda eksikliği olan öğretmenlerden sağlıklı bir yazma öğretimi gerçekleştirmesi beklenmemelidir. 


\section{Öneriler}

Bu çalışmada ulaşılan sonuçlar baglamında uygulayıcılar ve araştırmacılar için aşağıdaki öneriler sunulmuştur.

Uygulayıcılar için: Öğretmenlerin farklı metin türünde yazma çalışmaları yapabilmesi için her metin türünün özelliklerini bilmesi gerekir. Bu amaçla öğretmenlere farklı metin türlerinde yazma öğretimi becerisi kazandırılmalıdır. Öğretmenlerin yazma öğretimine ve yazma çalışmalarına daha fazla zaman ayıracağı koşullar sağlanmalıdır. Öğretmenlerin standart ölçme aracı geliştirme, kullanma ve farklı metin türlerine göre değerlendirme yapabilmesi için çalışmalar yapılmalıdır.

Araştırmacılar için: Bu çalışma, pandemi koşullarında ve 36 kişiyle yapıldığından daha büyük bir örneklemle ve yüz yüze veri toplama yöntemiyle çalışılmasında fayda vardır. Bu çalışma öğretmenlerin görüşlerine göre yapılmıştır. Bu tür çalışmalarda katılımcıların beyanlarına göre değerlendirme yapılır. Sınıf öğretmenlerinin, öğrenci metinlerini nasıl değerlendirdiğini birebir öğrenci metni üzerinden uygulamalı olarak görmenin ve sınıf içi gözlemlerden yararlanarak araştırma yapmanın daha faydalı olacağı düşünülmektedir.

Sınırlıklar: Bu çalışmanın sınırlıkları: Pandemi koşullarında öğretmenlerin uzaktan form doldurması, 36 kişiyle sinırlı olması ve kullanılan görüşme formu çerçevesinde ele alınmalıdır. Ayrıca, Covid-19 nedeniyle yaklaşık 10 aydır okuldan uzak (kesintili) ve eğitim-öğretim adına travmatik bir dönemde bulunan öğretmenlerden verilerin toplandığının bilinmesi de önemlidir. 
EXTENDED ABSTRACT

\section{Primary School Teachers' Evaluation Criteria for Written Expression \\ *

\author{
İlhan Polat - Hakan Dedeoğlu
} \\ Hacettepe University}

Primary school is a period in which the foundations of writing education are laid. In addition, it is the period in which written expression skills develop, and it is the period when students' feelings such as interest, attitude and anxiety towards writing are also shaped. In this process, the most important task both in teaching writing and in evaluation and feedback falls on the primary school teachers. In this context, the criteria to evaluate the writing skill of primary school teachers are very important. Because the criteria of teachers are an important factor both in shaping writing education and on students' feelings about writing. This makes it important to know which assessment criteria used by primary school teachers who laid the foundation of teaching writing.

The aim of this study is to investigate the criteria by which primary school teachers evaluate the texts written by their students. This study was designed as a case study with a holistic single case pattern among qualitative research methods. Participants consist of 36 primary school teachers. Participants were determined using the maximum diversity method. Diversity has been tried to be achieved by selecting teachers working in different cities and socio-economic environments. 25 of the teachers are men and 11 are women. Generally, teachers are experienced. Semi-structured interview technique was used in the research. Data was collected as a remote interview due to the Covid-19 outbreak. Some questions of the form prepared according to expert opinion are as follows: In which text types do you write? How many lessons per week do you devote to writing? Can you give an example of your writing work in the classroom? Do you use any scales to evaluate your students' texts? What characteristics do you pay attention to when evaluating the narrative texts written by your students? What characteristics do you pay at- 
tention to while evaluating the informative texts written by your students?

The data of the study were analyzed with the descriptive analysis technique. By giving the participants code names as T1, T2, T3..., the answers to each question were brought together and analyzes were made. First, sections were taken from the speeches and codes were determined according to the sections. The theme-category relationship of the section on narrative and informative texts was created according to the form prepared by Temizkan (2008). For validity and reliability: In the findings section, the theme, category and code table were created, the frequency value of the codes and the corresponding sample teachers' opinions were presented in a single table. The method part of the study is given in a clear, understandable and detailed way; Data collection tools, data collection process and analysis process were presented to readers and other researchers in detail. In the analysis of the data, two researchers coded separately. Teachers' views are classified in accordance with the literature. The form including study notes and participant opinions is kept. Permission was obtained from the Ethics Committee of Hacettepe University for this study.

According to the findings, the following results have been reached: Teachers mostly use narrative texts in their writing activities. All of the teachers devote time to writing every week. Most of the teachers stated that they allocate 1-2 hours to 3-4 hours. Story completion work is mostly done. The vast majority of teachers do not use a standard measurement tool, but instead evaluate according to their own criteria. Looking at the evaluation criteria according to the text types, when evaluating the narrative texts, the most paper layout, spelling rules and punctuation marks, self-expression skills, sentence structure, text integrity, story characters-hero, the sequence of events, text parts (Introduction, development, conclusion) and pays attention to the story's message. When evaluating informative texts, it was concluded that he mostly pays attention to the layout and legibility, spelling and punctuation marks, selfexpression, correct use of words, accuracy of information, ways of developing thought, researching the subject and text integrity. In general, it can be said that teachers have serious deficiencies in evaluating narrative and informative texts. Considering the frequency table of the responses 
given by the teachers, although some features that should be in the informative texts are specified, the frequency of these features is very low. As a result, primary school teachers have important deficiencies in evaluating students' written expressions. It is an important problem that teachers use their own criteria instead of standard measurement tools, do not spare enough time for writing, and provide variety in writing. The most important problem obtained from this study is the evaluation criteria of teachers. Teachers have stated some of the evaluation criteria according to the literature, but their frequency is quite low. While only a few criteria are expressed by half or more of the teachers, in many criteria this number falls to 2-3. In fact, many criteria are not even mentioned.

Teachers who do not devote enough time to teaching, do not provide writing diversity, make subjective evaluations, and lack the criteria for evaluating written expression should not be expected to perform a healthy writing education. According to the results, it is seen that teachers need a better education in and before the service in teaching writing and evaluation. Teachers should be supported in this regard. Since this study was conducted under pandemic conditions and with 36 people, it is beneficial to work with a larger sample face-to-face data collection method.

\section{Kaynakça / References}

Adıyaman, Y. (2005). Ilköğretim 4., 6. ve 8. sinıflarında Türkçe dersine giren öğretmenlerin ölçme -değerlendirme düzeyleri. Yüksek Lisans Tezi. Afyon Kocatepe Üniversitesi, Sosyal Bilimler Enstitüsü.

Akyol, H. (2019). Programa uygun Türkçe öğretim yöntemleri. (9. Baskı). Ankara: Pegem Akademi.

Arıcı, A. (2008). Üniversite öğrencilerinin yazılı anlatım hataları. Uludă̆ Üniversitesi Ĕ̆itim Fakültesi Dergisi, 21(2), 209-220.

Arıcı, A. ve Ungan, S. (2008). İlköğretim ikinci kademe öğrencilerinin yazılı anlatım çalışmalarının bazı yönlerden değerlendirilmesi. Dumlupınar Üniversitesi Sosyal Bilimler Dergisi, 20, 317-328.

Ateş, S. (2017). Öğretmen adaylarının perspektifinden sınıf içi yazma çalışmalarının değerlendirilmesi. Journal of Human Sciences, 14(2), 1534-1557. doi:10.14687/jhs.v14i2.3997 
Bağcl, H. (2010). Türkçe öğretmeni adaylarının yazılı anlatım yeterlilik düzeyleri. İnönü Üniversitesi Ĕ̆itim Fakültesi Dergisi, 11(2), 45-68.

Başar, T. ve Yavaşlı, M. (2020). Yazarlık ve yazma becerileri dersi öğretim programına yönelik öğretmen görüşleri. Ana Dili Eğitimi Dergisi, 8(2), 270291.

Benzer, A. ve Eldem, E. (2013), Türkçe ve edebiyat öğretmenlerinin ölçme ve değerlendirme araçları hakkında bilgi düzeyleri. Kastamonu Ĕ̆itim Fakültesi, 21(2), 649-664.

Brindle, M., Graham, S., Harris, K. R. and Hebert, M. (2016). Third and fourth grade teacher's classroom practices in writing: A national survey. Reading and Writing, 29(5), 929-954.

Coşkun, E. (2014). Yazma eğitimi. A. Kırkkılıç ve H. Akyol (Ed.) İlköğretimde Türkçe öğretimi içinde (s.49-91). Ankara: Pegem.

Coşkun, H. (2017). Türkçe öğretmeni adaylarını öğretim materyali olarak amaca uygun yazdıkları metinlerin değerlendirilmesi. Yüzüncü Yıl Üniversitesi Ĕ̆itim Fakültesi Dergisi, 14(1) , 458-482.

Coşkun, E. (2005). İlköğretim öğrencilerinin öyküleyici anlatımlarında bağdaşıklık, tutarlllık ve metin elementleri. Doktora Tezi. Gazi Üniversitesi, Eğitim Bilimleri Enstitüsü.

Crusan, D., Plakans, L. and Gebril, A. (2016). Writing assessment literacy: Surveying second language teachers' knowledge, beliefs, and practices. Assessing Writing, 28(2016) 43-56.

Cutler, L. and Graham, S. (2008). Primary grade writing instruction: A national survey. Journal of Educational Psychology, 100(4), 907-919.

Doğan-Kahtalı, B. ve Çelik, Ş. (2020). 2019 Türkçe öğretim programında ölçme ve değerlendirme ile Türkçe öğretmenlerinin ölçme ve değerlendirme araçlarını kullanma düzeyleri. Eğitim Kuram ve Uygulama Araştırmaları Dergisi, 6(2), 237-244.

Elma, C. ve Bütün, E. (2015). İlkokul ve ortaokul öğrencilerinin yazılı anlatım becerilerine ilişkin öğretmen görüşleri. Abant İzzet Baysal Üniversitesi Eğitim Fakültesi Dergisi, 15(2), 104-131.

Epçaçan, C. ve Erzen, M. (2008). İlköğretim Türkçe dersi öğretim programının değerlendirilmesi. Uluslararası Sosyal Araştırmalar Dergisi, 1(4),182-202.

Gelbal, S. ve Kelecioğlu, H. (2007). Öğretmenlerin ölçme ve değerlendirme yöntemleri hakkındaki yeterlik algıları ve karşılaştıkları sorunlar. $\mathrm{Ha}$ cettepe Üniversitesi Ĕ̆itim Fakültesi Dergisi, 33, 135-145. 
Gilbert, J. and Graham, S. (2010). Teaching writing to elementary students in grades 4-6: A national survey. The Elementary School Journal, 110, 494517.

Göçer, A. (2010). Türkçe öğretiminde yazma eğitimi. Uluslararası Sosyal Araştırmalar Dergisi, 3(12), 178-195.

Göçer, A. (2011). Öğrencilerin yazılı anlatım çalışmalarının Türkçe öğretmenlerince değerlendirilmesi üzerine. Ondokuz Mayıs Üniversitesi Eğitim Fakültesi Dergisi, 30(2), 71-97.

Graham, S., Bollinger, A., Booth Olson, C., D'Aoust, C., MacArthur, C., McCutchen, D. and Olinghouse, N. (2012). Teaching elementary school students to be effective writers: A practice guide. Washington, DC: National Center for Education Evaluation and Regional Assistance (NCEE), Institute of Education Sciences, U.S. Department of Education.

Güneş, F. (2019). Türkçe öğretimi yaklaşımlar ve modeller. Ankara: Pegem Akademi Yayıncilik.

Kan, M. ve Tiryaki, E. (2015). Türkçe öğretmeni adaylarının metin oluşturmadaki sorunları. Mersin Üniversitesi Ĕ̆itim Fakültesi Dergisi, 11(2), 550562.

Karadağ-Yılmaz R. ve Erdoğan, Ö. (2019). Yazma, yaratıcı yazma eğitimi. Türkçe öğretimi: Öğretmenler ve öğretmen adayları için. (Editör: Hayati Akyol ve Ayfer Şahin). Ankara: Pagem Akademi.

Karakoç-Öztürk, B. (2014). Türkçe öğretmenlerinin yazma eğitimine ve öğrencilerin öykü yazma becerilerine ilişkin görüşleri. International Journal of Language Academy, 2(4), 170-194.

Karakoç-Öztürk, B. (2016). Yazma becerisine ilişkin süregelen uygulamaların Türkçe dersi öğretim programı (2006) çerçevesinde değerlendirilmesi. Abant İzzet Baysal Üniversitesi Eğitim Fakültesi Dergisi, 16(4), 1921-1945.

Karatay, H. ve Dilekçi, A. (2019). Türkçe öğretmenlerinin dil becerilerini ölçme ve değerlendirme yeterlikleri. Millî Eğitim Dergisi, 48(1), 685716.

Kayabaşı, B. ve Karadağ-Yılmaz, R. (2019). Sınıf öğretmeni adaylarının yazma alışkanlıkları, tercihleri, tutum ve inançları. Kastamonu Ĕ̆itim Dergisi, 27(6) , 2529-2546. DOI: 10.24106/kefdergi.3417

Lucero, M., Fernández,M.J. and Montanero, M. (2018). Teachers' written feedback comments on narrative texts in elementary and secondary Education. Studies in Educational Evaluation, 59(2018), 158-167. 
Maltepe, S. (2006). Yaratıcı yazma yaklaşımı açısından Türkçe derslerindeki yazma süreçlerinin ve ürünlerinin değerlendirilmesi. Doktora tezi. Ankara Üniversitesi, Sosyal Bilimler Enstitüsü, Türkçenin Eğitimi Ve Öğretimi Anabilim Dal1, Ankara.

MEB (2019). Türkçe dersi (1-8. Sinıflar) öğretim programı. Ankara: Milli Eğitim Bakanlığı Talim Terbiye Kurulu Başkanlığı.

Sarikaya, İ. ve Yılar, R. (2018) Sınıf öğretmenlerinin yazılı değerlendirmeye yönelik görüşlerinin incelenmesi: Bayburt örneği. The 27th International Congress on Educational Sciences. s.1157-1165

Şimşek, Ş. (2015). Yazılı Anlatım Etkinlikleriyle İlgili Öğretmen-Öğrenci Algılarının Karşılaştırılması. Doktora tezi. Necmettin Erbakan Üniversitesi Eğitim Bilimleri Enstitüsü, Konya.

Tabak, G. ve Göçer, A. (2013). 6-8. sinıflar Türkçe dersi öğretim programının ürün ve süreç odaklı yazma yaklaşımları çerçevesinde değerlendirilmesi. Ahi Evran Üniversitesi Kırşehir Eğitim Fakültesi Dergisi (KEFAD), 14(2), 147-169

TED (2009). Öğretmen yeterlikleri - özet rapor. Ankara: Türk Eğitim Derneği Yayınları.

Temizkan, M. (2003). Yazll anlatım etkinliği çerçevesinde Türkçe öğretmenlerinin çalışmalarına ilişkin bir değerlendirme. Yüksek Lisans Tezi. Mustafa Kemal Üniversitesi, Sosyal Bilimler, Enstitüsü, Türkçe Eğitimi Anabilim Dall, Hatay.

Temizkan, M. (2008). Türkçe ve sınıf öğretmeni adaylarının yazılı anlatım çalışmalarını düzeltme ve değerlendirme durumları. Ahi Evran Üniversitesi Kırşehir Eğitim Fakültesi Dergisi, 9(3), 49-61.

Tiryaki, E. N. ve Kan, M.O. (2015) Türkçe öğretmeni adaylarının metin oluşturabilme becerileri. Zeitschrift für die Welt der Türken Journal of World of Turks, 7(2) ,183-192.

Uygun, M. ve Katrancı, M. (2013). Sınıf öğretmenlerinin Türkçe derslerinde karşılaştıkları sorunlara ilişkin görüşleri. Çankırı Karatekin Üniversitesi Sosyal Bilimler Enstitüsü Dergisi, 4(1), 255-270.

Ülper, H. (2012). Taslak metinlere öğretmenler tarafından sunulan geribildirimlerin özellikleri. Eğitim ve Bilim, 37(165), 121-136.

Vygostky, L. S. (1998). Düşünce ve dil. İstanbul: Toplumsal Dönüşüm Yayınları. 
Yamaç, A., ve Öztürk, E. (2018). Türkiye'deki ilkokul öğretmenlerinin yazma öğretimi uygulamaları ve algılarının değerlendirilmesi: Bir karma yöntem araştırması. Hacettepe Üniversitesi Ĕ̆itim Fakültesi Dergisi, 33(4), 846-867. doi: 10.16986/HUJE.2018037559

Yıldırım, A. ve Şimşek, H. (2018). Nitel araştırma yöntemleri. Ankara: Seçkin Yayıncilik.

Zorbaz, K. Z. (2013). Yazılı anlatımın puanlanması. Abant İzet Baysal Üniversitesi Ĕ̆itim Fakültesi Dergisi, 13(1), 178-192.

Zorbaz, M. (2019). Yazma kültürü: Türk Dili-Edebiyatı ve türkçe öğretmen adayları üzerine bir inceleme. Yüksek lisans tezi. Pamukkale Üniversitesi Eğitim Bilimleri Enstitüsü, Denizli.

\section{Kaynakça Bilgisi / Citation Information}

Polat, İ. ve Dedeoğlu, H. (2021). Sınıf öğretmenlerinin yazılı anlatımı değerlendirme ölçütleri. OPUS-Uluslararası Toplum Araştırmaları Dergisi, 18(Eğitim Bilimleri Özel Sayısı), 4642-4670. DOI: 10.26466/opus.890147. 